\title{
Patients' knowledge and beliefs about antiretroviral treatment and factors associated with adherence in Mpumalanga Province, South Africa
}

\begin{tabular}{|c|c|}
\hline \multicolumn{2}{|c|}{$\begin{array}{l}\text { Authors: } \\
\text { Thuli G. Mthembu } \\
\text { Brian van Wyk }{ }^{2}\end{array}$} \\
\hline \multicolumn{2}{|c|}{$\begin{array}{l}\text { Affiliations: } \\
{ }^{1} \text { Department of Occupational } \\
\text { Therapy, University of the } \\
\text { Western Cape, South Africa }\end{array}$} \\
\hline \multicolumn{2}{|c|}{$\begin{array}{l}{ }^{2} \text { School of Public Health, } \\
\text { University of the Western } \\
\text { Cape, South Africa }\end{array}$} \\
\hline \multicolumn{2}{|c|}{$\begin{array}{l}\text { Correspondence to: } \\
\text { Thuli Mthembu }\end{array}$} \\
\hline \multicolumn{2}{|c|}{$\begin{array}{l}\text { Email: } \\
\text { tmthembu@uwc.ac.za }\end{array}$} \\
\hline \multicolumn{2}{|c|}{$\begin{array}{l}\text { Postal address: } \\
25 \text { Edison Drive, Extension } \\
23 \text {, Belhar 7490, South Africa }\end{array}$} \\
\hline \multicolumn{2}{|c|}{$\begin{array}{l}\text { Dates: } \\
\text { Received: } 08 \text { Jan. } 2013 \\
\text { Accepted: } 28 \text { Mar. } 2014 \\
\text { Published: } 09 \text { July } 2014\end{array}$} \\
\hline \multicolumn{2}{|c|}{$\begin{array}{l}\text { How to cite this article: } \\
\text { Mthembu, T.G. \& Van } \\
\text { Wyk, B., 2014, 'Patients' } \\
\text { knowledge and beliefs about } \\
\text { antiretroviral treatment } \\
\text { and factors associated } \\
\text { with adherence', Health } \\
\text { SA Gesondheid 19(1), Art. } \\
\text { \#718, } 7 \text { pages. http://dx.doi. } \\
\text { org/10.4102/hsag.v19i1.718 }\end{array}$} \\
\hline \multicolumn{2}{|c|}{$\begin{array}{l}\text { Copyright: } \\
\text { (C) 2014. The Authors. } \\
\text { Licensee: AOSIS } \\
\text { OpenJournals. This wC } \\
\text { is licensed under the } \\
\text { Creative Commons } \\
\text { Attribution License. }\end{array}$} \\
\hline \multicolumn{2}{|l|}{ Read online: } \\
\hline 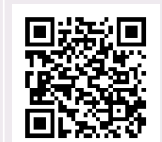 & $\begin{array}{l}\text { Scan this QR } \\
\text { code with your } \\
\text { smart phone or } \\
\text { mobile device } \\
\text { to read online. }\end{array}$ \\
\hline
\end{tabular}

Background: Antiretroviral treatment (ART) improves the prognosis and quality of life for HIV patients by reducing the rate of disease progression and mortality. Although ART has been available in public health centres in South Africa since 2003, adherence to treatment still remains a challenge. To date, no study has investigated adherence and the factors that influence adherence to ART in rural settings in Mpumalanga Province.

Objective: This study described adherence to, knowledge and beliefs about ART and other factors associated with adherence amongst patients registered at Shongwe Hospital in Nkomazi Local Municipality.

Method: A cross-sectional survey of 184 randomly selected patients on ART between ages of 15 and 65 years was conducted.

Results: The respondents completed a questionnaire on self-reported adherence, knowledge and beliefs about ART and other factors associated with adherence. The majority of the respondents were female $(71.2 \%)$ and unemployed $(83.7 \%)$. Most respondents reported optimal ART adherence (taking $95 \%$ or more of their medication as prescribed) over the past two (92.4\%) and seven (84.2\%) days, respectively. The level of knowledge about ART was high and most reported positive beliefs about the effectiveness of ART. However, slightly more than half $(53.3 \%)$ believed that ART was harmful for the body. The most commonly-reported reasons for missing dosages were forgetfulness, business of the daily routine, having visitors, 'visiting a bar' and sleeping away from home.

Conclusion: Although, the study found that most ART patients at Shongwe Hospital reported optimal adherence initially, the reasons for missing dosages, some incorrect knowledge and beliefs need to be addressed to ensure long-term adherence and persistence in care.

Agterground: Antiretrovirale (ARV) behandeling verbeter die prognose en lewenskwalitiet van pasiënte wat besmet is met MIV, deur 'n remmende effek op die ontwikkeling van VIGS te bewerkstellig. Alhoewel ARVbehandeling reeds sedert 2003 in openbare gesondheidsentrums in Suid Afrika beskikbaar was, bly die volgehoue en stiptelike navolging van die behandelingsplan 'n grootse uitdaging vir pasiënte. Daar is egter min navorsing oor die faktore wat navolging van ARV behandeling deur pasiënte in landelike gebiede in Mpumalanga gedoen.

Doelwitte: Hierdie studie ondersoek pasiënte se kennis, houdings en ander faktore wat die navolging van ARV behandeling beïnvloed by Shongwe-hospitaal in die Nkomazi distrik in Mpumalanga.

Metode: 'n Bestekopname van 184 pasiënte, tussen die ouderdomme van 15 en 65 jaar, wat ARV behandeling ontvang is gedoen. Hulle is lukraak gekies en het ' $n$ vraelys voltooi rakende hul kennis en oortuigings ten opsigte van ARV-middels, asook die faktore wat die stiptelike gebruik van die middels beïnvloed.

Resultate: Die steekproef het hoofsaaklik uit vroue (71.2\%) bestaan, en die meerderheid was werkloos (83.7\%). Die meeste van die deelnemers het aangedui dat hulle hul ARV-medikasie die vorige twee dae $(92.4 \%)$ en sewe dae $(84.2 \%)$ grotendeels (ten minste $95 \%$ van medikasie) volgens voorskrif geneem het. Die meerderheid van die studie deelnemers het redelike kennis van en positiewe houdings teenoor ARV-behandeling getoon. Vergeetagtigheid, die besigheid van normale daaglikse roetine, die ontvang van besoekers, besoeke aan kroeë asook uitslaap was die redes wat aangevoer is vir vernalating om medisyne te neem.

Gevolgtrekking: Alhoewel, die meeste pasiënte in hierdie studie aanvanklik redelik goed gevaar het met die navolging van die behandelingsplan, moet die probleme wat ervaar is met die neem van medikasie aangespreek word om lang-termyn navolging van behandeling en retensie te bewerkstellig. 


\section{Introduction}

HIV and AIDS are major public health problems facing South Africa today (Hosegood et al. 2007:1249; Woods, Cope \& Eley 2008:15). According to the World Health Organization [WHO] (2013), South Africa has the largest antiretroviral treatment (ART) programme in the world, with about 2.2 million people on HIV treatment in 2012. This is almost 500000 more than in 2011 when 1702060 South Africans were receiving ART. This shows that South Africa has achieved an increase in ART coverage from 71\% in 2011 to 83\% in 2012 (WHO 2013). South Africa has also improved the eligibility threshold for initiation of HIV treatment from a CD4+ count of 200 cells $/ \mathrm{mm}^{3}$ to 350 cells $/ \mathrm{mm}^{3}$ (Department of Health 2011; WHO 2013). This policy change has resulted in an increased number of people initiating ART in government clinics and hospitals.

Highly Active Antiretroviral Therapy (HAART) is the recommended form of treatment for advanced HIV disease (WHO 2006a). HAART is a triple therapy that uses three or more antiretroviral drugs from at least two of the medication classes. The purpose of this drug cocktail is to stop the progression of HIV, reduce the HIV viral load in the blood and increase the CD4+ cell count of the patient to a baseline count of between 500 and 2010 cells $/ \mathrm{mm}^{3}$ (Trotta et al. 2010). HAART can be effective in controlling the level of HIV to a point where the virus is no longer detectable in the blood of infected individuals (Dieckhaus \& Odesina 2007:81). As a result, ART increases the life expectancy and improves the quality of life of patients with HIV (Roberts 2000:155). The effectiveness of ART gives patients hope that if they adhere to the treatment regimen, they will be able to live productive lives (Carrieri et al. 2006).

However, the HAART regimen is extremely complicated and has strict rules regarding when the patients must take their drugs (Roberts 2000:155). In addition, antiretroviral drugs are psychologically and physiologically demanding as patients need to swallow a large numbers of pills each day and may experience side effects. Another negative factor regarding the triple therapy is that if HIV-infected individuals miss doses or take the drugs improperly, they could develop resistance to one or more of the drug classes.

\section{Problem statement}

Although ART has been available through public health centres in South Africa since 2003, poor adherence is recognised as a challenge to HIV care and treatment programmes, both in South Africa and in the rest of subSaharan Africa (Kyser et al. 2011; WHO 2006b). Given the shortages in human resources for health, HIV and AIDS programmes struggle to monitor adherence and retain large numbers of patients (Chesney et al. 2000:256). It has been shown that an individual's knowledge and beliefs about a specific treatment may influence their willingness to comply or adhere to the treatment regimen (Wasti et al. 2012). Studies on adherence to ART have also shown that contextual factors - in the community, health services and socio-economic environment - may influence the patient's ability and motivation to adhere to treatment (Musheke, Bond \& Merten 2012). In order to address the topic of adherence, the factors that may lead to poor adherence have to be investigated.

To date, no study has been conducted to describe knowledge and beliefs about ART and the factors that may influence adherence amongst ART patients in Nkomazi Local Municipality. The findings of such a study could be used to develop interventions to improve adherence to ART amongst patients in this region, as well as settings with similar characteristics.

\section{Aims of the study}

This study aimed to describe knowledge and beliefs about ART and factors associated with adherence among patients at Shongwe Hospital in Nkomazi Local Municipality in Mpumalanga province, South Africa.

\section{Research method and design Research design}

Between January and March 2009, we conducted a descriptive, cross-sectional study of knowledge and beliefs about ART and the factors associated with adherence amongst patients receiving ART at Shongwe Hospital in Nkomazi Local Municipality in the Mpumalanga province, South Africa. The quantitative approach was chosen because it offered quantitative information about adherence and the factors that are known to be associated with adherence (Leedy \& Ormrod 2005; Tewksbury 2009). Furthermore, employing the cross-sectional design provided an opportunity to test the significance of knowledge and beliefs and other factors related to adherence, with adherence (Tewksbury 2009).

\section{Population and sampling}

The study population consisted of patients who had been on ART for at least six months, were between the ages 15 and 65 years and were registered in the HAART programme at Shongwe Hospital. By mid-2008 there were 3000 people registered for ART in this hospital. Burns and Grove (2005:341) describe eligibility criteria or inclusion criterion as being a list of characteristics essential for eligibility in the study population.

A sample size calculation for the study was conducted in the StatCalc function of Epi Info version 3.4.1 and yielded a sample size of 184 patients on ART who were selected in order to collect the data. A simple random sample of patients on antiretroviral treatment was recruited from the hospital's ART register. A number was assigned to each name on the list (e.g. 1 to 3000). Numbers were then drawn from the box (by a neutral person) until the number for the sample (184) was reached. 


\section{Data collection}

The data were collected between January and March 2009 by means of a self-administered questionnaire. The questionnaire allowed for standardisation of the questioning, thereby increasing the reliability of the respondents' responses (Leedy \& Ormrod 2005). A previously-validated questionnaire on adherence to ART was adapted for the current study (Godin, Gagné \& Naccache 2003). The questionnaire comprised three sections, namely, sociodemographic characteristics, knowledge and beliefs about ART and adherence to ART. It took the respondents approximately 30 to 45 minutes to complete the questionnaire. In the cases where respondents were unable to read, the researcher asked the questions in a consistent manner and recorded the answers on behalf of the respondents.

\section{Data analysis}

During fieldwork, the data were checked regularly in order to ensure that they had been entered correctly in the correct item blocks or lines as the data could easily be entered in the incorrect place. The questionnaire included both numerical and categorical data. The data were captured twice in separate files using Microsoft Office Excel (2007) in order to ensure accuracy and completeness, before it was imported to the Statistical Package for Social Sciences (SPSS) version 16.0.0.1, 2007 (IBM Software) and Epi Info version 3.4.1 software. The procedure followed for statistical analysis includes three essential steps in data analysis.

Firstly, each variable was analysed separately, in sequence, for the distribution of counts in each category. The respondents' ages were grouped in order to obtain range, means and standard deviation. All categorical variables were then tabled to produce the frequency distributions. The respondents were stratified into two groups according to their adherence: optimal adherence - for those who took $\geq 95 \%$ of their medications; and suboptimal adherence - for those who took $<95 \%$ of their medications. Secondly, analyses were performed on pairs of variables that were relevant and these were then stratified accordingly. This cross-tabulation was done to test significance of associations between type of adherence and sociodemographic variables such as age, gender, education and economic status, various items of knowledge and beliefs, as well as other factors. Thirdly, the chi-square test was used and a $95 \%$ level of significance $(p<0.05)$ was used as the cut-off.

\section{Results}

\section{Socio-demographic characteristics of the respondents}

There were more female $(n=131 ; 71.2 \%)$ than male respondents in the current study sample with a female: male ratio of $\sim 2: 1$ (Table 1 ). The mean age of the study sample was $38.87 \pm 10.27$ years with a range of 15 to 65 years. The male respondents were, on average, older than the female respondents (44.32 \pm 9.83 years vs. $36.67 \pm 9.63$ years). Most $(n=33 ; 62.2 \%)$ of the male participants in the study were 40 years and older, compared with female participants who were mostly younger than 40 years $(n=13$ [9.9\%] between 15 and 24 years old and $n=74$ [56.5\%] between 25 and 39 years old).

Whereas most female patients in the study were single ( $n=84 ; 64.1 \%$ ), the men were mostly 'ever' married, that is to say, either married or cohabitating $(n=28 ; 52.8 \%)$, widowed $(n=6 ; 11.3 \%)$ or divorced or separated $(n=2 ; 3.8 \%)$. Female respondents were better educated, with $74(56.5 \%)$ and $4(3.1 \%)$ having secondary school and tertiary education, respectively; compared with male respondents, where only $26(49.1 \%)$ had obtained secondary school education. Unemployment was high in the study sample; 40 (75.5\%) of the men and $114(87 \%)$ of the women were unemployed.

\section{Reported adherence to antiretrovirals}

The majority ( $n=179 ; 97 \%$ ) had disclosed their HIV status to a sibling, parent, grandparent or aunt/uncle. Almost all $(n=179 ; 97.3 \%)$ of the respondents reported that they disclosed being on ART to someone.

Most of the respondents reported optimal ART adherence (taking $95 \%$ or more of their medication as prescribed) over the past two days $(n=170 ; 92.4 \%)$ and seven days $(n=155$; $84.2 \%)$, respectively. However, there was a small proportion of respondents $(n=39 ; 15.8 \%)$ who reported suboptimal $(<95 \%)$ adherence to ART. Nearly $60.3 \%(n=111)$ of the female respondents reported optimal ( $\geq 95 \%$ ) adherence to ART over the past seven days, compared with 44 (23.9\%) of the male respondents. However, there was a small proportion of the male respondents $(n=9 ; 4.8 \%)$ who reported suboptimal $(<95 \%)$ adherence to ART (Figure 1$)$.

TABLE 1: Sociodemographic characteristics of the respondents $(N=184)$.

\begin{tabular}{|c|c|c|c|c|c|c|}
\hline \multirow[t]{2}{*}{ Variable } & \multicolumn{2}{|c|}{ Male } & \multicolumn{2}{|c|}{ Female } & \multicolumn{2}{|c|}{ Total } \\
\hline & $n$ & $\%$ & $n$ & $\%$ & $n$ & $\%$ \\
\hline \multicolumn{7}{|l|}{ Age (in years) } \\
\hline $15-24$ & - & - & 13 & 9.9 & 13 & 7.1 \\
\hline $25-39$ & 20 & 37.7 & 74 & 56.5 & 94 & 51 \\
\hline $40-49$ & 19 & 35.8 & 33 & 25.2 & 52 & 28.3 \\
\hline$\geq 50$ & 14 & 26.4 & 11 & 8.4 & 25 & 13.6 \\
\hline \multicolumn{7}{|l|}{ Marital status } \\
\hline Single & 17 & 32.1 & 84 & 64.1 & 101 & 54.9 \\
\hline Married/Cohabiting & 28 & 52.8 & 16 & 12.2 & 44 & 23.9 \\
\hline Widowed & 6 & 11.3 & 24 & 18.3 & 30 & 16.3 \\
\hline Divorced/Separated & 2 & 3.8 & 7 & 5.3 & 9 & 4.9 \\
\hline \multicolumn{7}{|l|}{ Education } \\
\hline No schooling & 7 & 13.2 & 13 & 9.9 & 20 & 10.9 \\
\hline Primary school & 20 & 37.7 & 40 & 30.5 & 60 & 32.6 \\
\hline Secondary school & 26 & 49.1 & 74 & 56.5 & 100 & 54.3 \\
\hline Tertiary & - & - & 4 & 3.1 & 4 & 2.2 \\
\hline \multicolumn{7}{|l|}{ Employment status } \\
\hline Employed & 13 & 24.5 & 17 & 13 & 30 & 16.3 \\
\hline Unemployed & 40 & 75.5 & 114 & 87 & 154 & 83.7 \\
\hline
\end{tabular}




\section{Knowledge and beliefs about antiretroviral therapy}

All respondents reported that they believe that ART is effective and that it could improve their quality of life. Knowledge of the importance of adherence was shared amongst all respondents, as they indicated correctly that missing doses of ART leads to disease progression. The majority of the respondents $(n=140 ; 76.1 \%)$ indicated correctly that HIV cannot be cured with ART, whereas almost a quarter of the respondents ( $n=44 ; 23.9 \%)$ were of the erroneous belief that HIV can be cured with ART (Table 2). Further revelations in this study included the fact that 38 (20.3\%) of the respondents did not believe that ART can prevent transmission of HIV from mother to child. More than half of the respondents ( $n=98 ; 53.3 \%)$ believed, incorrectly, that ART is harmful

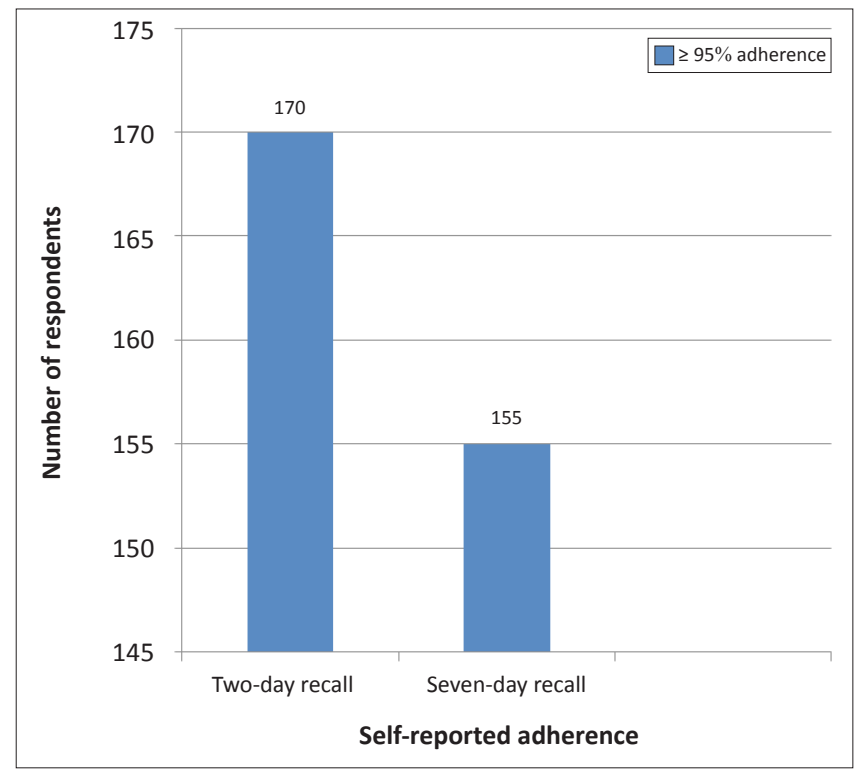

FIGURE 1: Self-reported adherence to antiretroviral therapy over two- and seven-day recall.

TABLE 2: Knowledge and beliefs about antiretroviral therapy.

\begin{tabular}{|c|c|c|c|c|c|c|}
\hline \multirow[t]{2}{*}{ Questions } & \multicolumn{2}{|c|}{ Female } & \multicolumn{2}{|c|}{ Male } & \multicolumn{2}{|c|}{ Total } \\
\hline & $N$ & $\%$ & $n$ & $\%$ & $n$ & $\%$ \\
\hline $\begin{array}{l}\text { ART prevents mother to child } \\
\text { transmission? } \dagger\end{array}$ & 114 & 87 & 32 & 60.4 & 146 & 79.3 \\
\hline HIV can be controlled by ART? $\dagger$ & 128 & 97.7 & 52 & 98.1 & 180 & 97.8 \\
\hline ART is effective and prolongs life? $\dagger$ & 131 & 100 & 53 & 100 & 184 & 100 \\
\hline HIV cannot be cured by ART?† & 100 & 76.3 & 40 & 75.5 & 140 & 76.1 \\
\hline $\begin{array}{l}\text { Taking ART prevents disease } \\
\text { progression } \dagger\end{array}$ & 130 & 99.2 & 51 & 96.2 & 181 & 98.4 \\
\hline $\begin{array}{l}\text { Not taking ART when indicated can } \\
\text { make you sick?† }\end{array}$ & 131 & 100 & 53 & 100 & 184 & 100 \\
\hline ART improves quality of life? $\dagger$ & 131 & 100 & 53 & 100 & 184 & 100 \\
\hline $\begin{array}{l}\text { Antiretroviral medicine can cause side } \\
\text { effects?† }\end{array}$ & 123 & 93.9 & 48 & 90.6 & 171 & 92.9 \\
\hline $\begin{array}{l}\text { Missing doses of ART leads to disease } \\
\text { progression? } \dagger\end{array}$ & 130 & 99.2 & 53 & 100 & 183 & 99.5 \\
\hline $\begin{array}{l}\text { Unprotected sex while missing doses } \\
\text { of ART, may lead to the transmission } \\
\text { of resistant strains? } \uparrow\end{array}$ & 127 & 96.9 & 51 & 96.2 & 178 & 96.7 \\
\hline Believe ART is harmful to your body? & 67 & 51.1 & 31 & 58.5 & 98 & 53.3 \\
\hline $\begin{array}{l}\text { Believe traditional medicine is not } \\
\text { more effective than prescribed } \\
\text { medication? } \dagger\end{array}$ & 131 & 100 & 53 & 100 & 184 & 100 \\
\hline
\end{tabular}

to their body. Most of the respondents ( $n=170 ; 92.9 \%$ ) identified correctly the fact that ART has side effects and almost all of the respondents $(n=181 ; 98.4 \%)$ believed that taking ART prevents disease progression. A small number of respondents $(n=6 ; 3.3 \%)$ did not believe that unprotected sex whilst missing doses of ART may lead to the transmission of resistant strains. All of the respondents reported that they did not believe that traditional medicine is more effective than HIV medication.

\section{Factors associated with adherence to antiretroviral therapy}

Respondents who knew that 'missing doses of ART leads to disease progression' were significantly more likely to report suboptimal adherence over the past two days $\left(\chi^{2}=12.2092\right.$; $p=0.00)$ and seven days $\left(\chi^{2}=5.3740 ; p=0.02\right)$ than respondents who got this question wrong. There was a significant association between disclosure of HIV status and suboptimal ART adherence over two-day recall $\left(\chi^{2}=5.83\right.$; $p=0.01)$, but not on the seven-day recall $\left(\chi^{2}=0.00 ; p=0.95\right)$.

Respondents who disclosed being on ART were significantly more likely to report suboptimal adherence over the previous two days $\left(\chi^{2}=7.67 ; p=0.00\right)$ and seven days $\left(\chi^{2}=7.576\right.$; $p=0.00)$ compared with those who did not disclose being on ART. Also, respondents who attended support groups were more likely to report suboptimal adherence over two-day recall $\left(\chi^{2}=5.34 ; p=0.02\right)$ compared with those who did not attend support groups. This difference was not observed on seven-day recall of adherence.

Respondents who received visits from friends or family reported this to be a significant barrier to optimal adherence based on two-day and seven-day recall $\left(\chi^{2}=7.09, p=0.00\right.$; and $\chi^{2}=5.74 ; p=0.01$, respectively) compared with those who did not receive visitors. Those respondents who visited a bar were significantly more likely to have suboptimal adherence on the seven-day recall than those who did not visit a bar $\left(\chi^{2}=4.5440 ; p=0.03\right)$.

Forgetfulness was found to be associated significantly with suboptimal ART adherence over the previous two days $\left(\chi^{2}=8.91 ; p=0.00\right)$ and seven days $\left(\chi^{2}=69.33 ; p=0.00\right)$.

Results of this study show that there were no significant differences found between optimal adherence to ART and the following demographic characteristics: age, marital status, education level and employment status.

\section{Ethical considerations}

According to Kelley et al. (2003), conducting research ethically covers the research project from the identification of the research topic to the publication of the study results. The study was approved by the University of the Western Cape Ethics and Higher Degrees Committee as well as the Mpumalanga Provincial Research Ethics Committee of Department of Health and Shongwe Hospital Management. 
TABLE 3: Factors associated with adherence to antiretroviral therapy over twoand seven-day recall.

\begin{tabular}{lcccccc}
\hline Variables & \multicolumn{2}{c}{ Two-day recall } & & \multicolumn{2}{c}{ Seven-day recall } \\
\cline { 2 - 3 } \cline { 6 - 7 } & $\chi^{2}$ & $p$-value & & $\chi^{2}$ & $p$-value \\
\hline $\begin{array}{l}\text { Missing doses of ART leads to disease } \\
\text { progression }\end{array}$ & 12.20 & $0.00^{*}$ & & 5.37 & $0.02^{*}$ \\
Disclosed HIV status & 5.83 & $0.01^{*}$ & & 0.00 & 0.95 \\
Disclosed being on ART & 7.67 & $0.00^{*}$ & & 7.57 & $0.00^{*}$ \\
Attended a support group & 5.34 & $0.02^{*}$ & & 0.43 & 0.50 \\
Attended meetings & 0.80 & 0.36 & & 4.52 & $0.03^{*}$ \\
Received visitors & 7.09 & $0.00^{*}$ & & 5.74 & $0.01^{*}$ \\
Visited a bar & 0.00 & 0.94 & & 4.54 & $0.03^{*}$ \\
Forgetful & 8.91 & $0.00^{*}$ & & 69.33 & $0.00^{*}$ \\
Sleeping away from home & 1.02 & 0.31 & & 20.29 & $0.00^{*}$ \\
Daily routine & 2.87 & 0.90 & & 16.30 & $0.00^{*}$ \\
\hline
\end{tabular}

ART, antiretroviral therapy; $\chi^{2}$, test of independence.

*, $p$-value, 0.05

The respondents were provided with an information sheet explaining the purpose of the research study, requesting their participation and assuring them of confidentiality. A consent form used for respondents was attached to the questionnaires and signed by the respondents after the study had been explained to them in full. Respondents gave informed consent to participate in the study and were informed in advance that participation in the study is voluntary and that they may withdraw at any stage. The respondents' right to anonymity was observed by using numbers instead of names, so that confidentiality could be assured during the dissemination of results. The respondents were also informed that no harm or benefits could be expected from the study, as it was being conducted for academic purposes. Furthermore, the respondents were protected with regard to no physical, emotional or social harm being caused during the study.

\section{Validity and reliability Validity}

Face validity is the appearance of the questionnaire (De Vos et al. 2005) and content validity refers to the extent to which the items on the questionnaire assess the content or how well the content material was sampled (Rubio et al. 2003). Content validity is further based on the extent to which a measurement reflects the specific intended domain of the content (Flores \& Antonsen 2013). This approach presumes that a good, detailed description of the content domain must be in place. Healthcare providers at the voluntary counseling and testing clinic at Shongwe Hospital were given the questionnaire to view before it was used for the main study. The researcher translated the questionnaire into siSwati as the predominant first language of the study population. The questionnaire was found to be relevant by the healthcare providers in the context of Shongwe Hospital.

\section{Reliability}

Instrument bias was reduced by using structured questionnaires adapted from Casey (ASEAN Secretariat 2004) and Godin et al. (2003). Reliability was enhanced by ensuring that questions were asked according to the set order on the questionnaire. Similarly, the researcher did not expand and probe more than was anticipated according to the questionnaire. A pilot study was conducted with the five healthcare workers at the clinic to test the instrument for further adjustment in an attempt to avoid ambiguity and input from the healthcare workers was of assistance when it came editing some of the questions.

\section{Discussion}

In the current study on knowledge and beliefs about antiretroviral treatment and factors associated with adherence to ART at Shongwe Hospital in Nkomazi region in Mpumalanga province, there were more female than male respondents. This is consistent with other studies conducted in ART programmes (Talam et al. 2008; WHO 2006b). This finding concurs with other research which suggested that men's poor health-seeking behaviour may present a barrier to them accessing ART services (Cornell 2013). In this study, education level was not associated significantly with adherence to antiretroviral treatment. This may be because the respondents were mostly educated at secondary school level or higher, which is rather surprising for such a rural setting. Unemployment was high amongst respondents in this study, which resonates with the fact that Nkomazi region is a rural district with limited employment opportunities.

The majority of the respondents in this study reported that they have disclosed their HIV status (97\%) and being on ART $(97.3 \%)$ to a significant other. This result is in contrast to other studies that found that HIV-related discrimination and stigmatisation are barriers to disclosure amongst people living with HIV. This is supported by Wasti et al. (2012) who suggested that disclosure of HIV status should be discussed during counseling sessions. However, patients with HIV are required to have a treatment buddy in public health programmes in South Africa as part of the preparation for being placed on ART, which possibly explains these high disclosure rates.

The results of this study concur with studies by Batamwita et al. (2011) and Wakibi, Ng'ang'a and Mbugua (2011). Nevertheless, some respondents had incorrect and inadequate knowledge about antiretroviral therapy, such as that HIV can be cured with ART. These results are further consistent with those studies of Batamwita et al. (2011) and de Castro Almeida and Fernandes Vieira (2009) who reported that respondents indicated that antiretroviral therapy kills HIV and cures AIDS. On the question of whether ART prevents mother-to-child transmission, this study found that a proportion of respondents in the study did not believe that ART might fulfil this function. This finding is consistent with the findings of Agnarson et al. (2013) who found that respondents in a cross-sectional survey in rural Tanzania had inadequate knowledge on treatment and prevention for HIV-infected pregnant women. As in the current study, the respondents in their study did not believe that ART prolongs life and thought that ART should be used only when people with HIV become very sick. 
Factors that were found to be associated significantly with suboptimal adherence included: experiencing side effects, knowing that missing doses of ART leads to disease progression, disclosing HIV status, disclosing being on ART, attending a support group, attending meetings, receiving visitors, visiting bars, being forgetful, sleeping away from home and being involved in the business of their daily routine. Women in the current study had higher suboptimal adherence when compared with the men. This corroborates the findings of Wasti et al. (2012) who found that women were more likely to be non-adherent with regard to their antiretroviral treatment. This result may be explained by the fact that women are most regularly responsible for care of their household and children and, therefore, the 'busy-ness' of the daily routine influences their adherence. The factors identified in this study are consistent with the literature in developing and developed countries when it comes to adherence to antiretroviral treatment. A small proportion of patients reported missing more pills over the seven days compared with the two-day recall. This finding confirms what is well established from the literature, that forgetfulness and being away from home have a negative effect on adherence to antiretroviral therapy (Dieckhaus \& Odesina 2007; Roberts 2000; Talam et al. 2008; Wakibi et al. 2011).

\section{Limitations of the study}

This study was cross-sectional and, therefore, the results are subject to bias. With this in mind, there are several limitations to the present study that may affect the validity and generalisation of the results. The results of this study must, therefore, be interpreted in the light of its limitations. The current study was conducted at a single site at Ehlanzeni district, Nkomazi Local Municipality, which rolls out ART, however caution must be applied, as the findings might not be transferable to other health facilities that are rolling out ART. The results of this study may also not be generalised to other health facilities delivering ART services because of the small sample size. The study used self-reporting to measure adherence to ART over seven days. However, this method of measuring adherence is known to produce overestimation and recall bias. The study was conducted to provide additional information about patients on ART and their adherence on medication. In addition, this study used a cross-sectional survey because of the nature of this design, which is known to provide only prevalence ratios and not causes. It would be inappropriate to imply that factors found to be associated with adherence to ART are the main causes. The healthcare providers who administer ART at the site were excluded from this study. Their participation could possibly have assisted in the researchers' understanding of adherence behaviour.

\section{Recommendations}

This study demonstrates that patients on ART have challenges with regard to taking their antiretroviral medication as instructed; therefore, the challenges appear to contribute to non-adherence. In the light of the study findings, the following recommendations were made for healthcare providers, policy makers and further research.

\section{Healthcare providers}

It is recommended that healthcare providers should monitor all patients on ART in order to identify those who might be susceptible to non-adherence to antiretroviral medication and to create supportive environments conducive to adherence for those patients. This will serve as a platform for patients to express how they use their HIV treatment. It will also address both incorrect knowledge and beliefs during adherence classes in order to reinforce correct information and the benefits of ART. Furthermore, the findings of this study may be used during education and counseling of patients who initiate treatment and those already in treatment. Healthcare providers should promote strategies for reminders such as cell phones, family members and treatment buddies. These strategies should be covered during education and counseling in order to address the issue of forgetfulness.

\section{Policy makers}

From the results, it was noted that the majority of patients were unemployed. There is thus a need for a strengthening of the intersectoral collaboration amongst different departments in order to enhance the country's Integrated Development Plan (Department of Health, Department of Social Development, Department of Agriculture and Department of Labour). Furthermore, the intersectoral collaboration could assist in establishing income-generating projects for people living with HIV so that they can meet the financial needs that affect their well being.

\section{Research}

There is a need to conduct a qualitative study to explore and describe patients' perceptions about the utilisation of antiretroviral therapy. Further research should be aimed at assessing men's knowledge and beliefs about HIV and antiretroviral therapy in the Nkomazi region.

\section{Conclusion}

This study has shown that the majority of patients on ART in this rural setting showed good adherence early in their treatment, despite various challenges related to disclosure, side effects and the social environment. To promote longterm adherence and retention in care, the challenges to adherence need to be addressed in both the community and health settings, as well as on individual level.

\section{Acknowledgements}

The authors would like to thank all the persons who granted them the permission to conduct the study: all respondents, VCT Shongwe Hospital staff, Mpumalanga Province Research Ethics Committee, University of the Western Cape Higher Degrees and Senate Research Committee and the reviewers of the article prior to submission. 


\section{Competing interests}

The authors declare that they have no financial or personal relationship(s) which may have inappropriately influenced them in writing this article.

\section{Authors' contributions}

T.G. (University of the Western Cape) was a Master's student whilst working at Shongwe Hospital and was responsible for conducting the study and writing the manuscript. B.d.W. (University of the Western Cape) supervised the student and co-authored the article.

\section{References}

Agnarson, A.M., Levira, F., Masanja, H., Ekström, A.M. \& Thorson, A., 2013, 'Antiretroviral treatment knowledge and stigma - implications for programs and HIV treatment interventions in rural Tanzanian populations', PLOS ONE 8(1), e53993. http://dx.doi.org/10.1371/journal.pone.0053993

ASEAN Secretariat, 2004, Adherence counselling for injecting drug users: treatment and care for HIV-positive injecting drug users (Participant manual, Module 7), viewed 15 April 2014, from http://cedoc.cies.edu.ni/general/World\%20 Health\%20Organization\%20HIV-AI\%20(D)2/pdfs/Publications_Module_07_ Treatment_\&_Care.pdf

Batamwita, R., Moore, D.M., King, R., Mills, E. \& Stangl, A.L., 2011, 'Assessment of antiretroviral therapy knowledge and willingness of persons with HIV to support its uptake in Uganda', Patient Preference and Adherence 5, 499-506. http:// dx.doi.org/10.2147/PPA.S23289

Burns, N. \& Grove, S.K., 2005, The practice of nursing research: conduct, critique, and utilization, 5th edn., Saunders, Philadelphia, PA.

Carrieri, M.P., Leport, C., Protopopescu, C., Cassuto, J.P., Bouvet, E., Peyramond, D. et al., 2006, 'Factors associated with nonadherence to highly active antiretroviral therapy: A 5-year follow-up analysis with correction for the bias induced by missing data in the treatment maintenance phase', Journal of Acquired by missing data in the treatment maintenance phase, Journal of Acquired
Immune Deficiency Syndromes 41(4), 477-485. http://dx.doi.org/10.1097/01 Immune Deficiency Syndrome

Chesney, M.A., Ickovics, J.R., Chambers, D.B., Gifford, A.L., Neidig, J., Zwickl, B. et al . 2000 , 'Self-reported adherence to antiretroviral medication among participants in HIV clinicals trials: the AACTG adherence instruments', AIDS Care 12(3), 255-266. http://dx.doi.org/10.1080/09540120050042891

Cornell, M., 2013, 'Gender inequality: bad for men's health', Southern African Journal of HIV Medicine [S.I.], 14(1), 12-14, viewed 26 February 2014, from http://www. of HIV Medicine [S.I.], 14(1), 12-14, viewed 26 February 2014,
sajhivmed.org.za/index.php/sajhivmed/article/view/894/781

De Castro Almeida, R.F. \& Fernandes Vieira, A.P.G., 2009, 'Evaluation of HIV/AIDS patients' knowledge on antiretroviral drugs', Brazilian Journal of Infectious Diseases 13(3), 183-190. http://dx.doi.org/10.1590/S1413-86702009000300006

De Vos, A.S., Strydom, H., Fouché, C.B. \& Delport, C.S.L., 2005, Research at grass roots, 3rd edn., Van Schaik Publishers, Pretoria.

Department of Health (South Africa), 2011, National Strategic Plan on HIV, STIs and TB: 2012 - 2016, Health Systems Trust. Available from http://www.hst.org.za/ publications/national-strategic-plan-hiv-stis-and-tb-2012-2016
Dieckhaus, K.D. \& Odesina, V., 2007, 'Outcomes of a multifaceted medication adherence intervention for HIV-positive patients', AIDS Patient Care and STDs 21(2), 81-91. http://dx.doi.org/10.1089/apc.2006.0044

Flores, W.R. \& Antonsen, E., 2013, 'The development of an instrument for assessing information security in organizations: examining the content validity using quantitative methods', CONF-IRM 2013 Proceedings, Paper 44, Available from http://aisel.aisnet.org/confirm2013/44

Godin, G., Gagné, C. \& Naccache, H., 2003, 'Validation of a self-reported questionnaire assessing adherence to antiretroviral medication', AIDS Patients Care and STDs 17(7), 325-332. http://dx.doi.org/10.1089/108729103322231268

Hosegood, V., Preston-Whyte, E., Busza, J., Moitse, S. \& Timaeus, I.M., 2007, 'Revealing the full extent of households' experiences of HIV and AIDS in rural South Africa', Social Science and Medicine 65(6), 1249-1259. http://dx.doi.org/10.1016/j. socscimed.2007.05.002

Kelley, K., Clark, B., Brown, V. \& Sitzia, J., 2003, 'Good practice in the conduct and reporting of survey research', International Journal for Quality in Health Care 15(3), 261-266. http://dx.doi.org/10.1093/intqhc/mzg031

Kyser, M., Buchacz, K., Bush, T.J., Conley, L.J., Hammer, J., Henry, K. et al., 2011, Factors associated with non-adherence to antiretroviral therapy in the SUN study, AIDS Care: Psychological and Socio-medical Aspects of AIDS/HIV 23(5), 601-611.

Leedy, P.D. \& Ormrod, J.E., 2005, Practical Research: Planning and Design, 8th edn., Pearson Merrill Prentice Hall, New Jersey.

Musheke, M., Bond, V. \& Merten, S., 2012, 'Individual and contextual factors influencing patient attrition from antiretroviral therapy care in an urban community of Lusaka, Zambia', Journal of the International AIDS Society 15(Supp 1), 17366. http://dx.doi.org/10.7448/IAS.15.3.17366

Roberts, K.J., 2000, 'Barriers to and facilitators of HIV-positive patients' adherence to antiretroviral treatment regimens', AIDS Patients Care and STDs 14(3), 155-168. antiretroviral treatment regimens', AlDS Patie
http://dx.doi.org/10.1089/108729100317948

Rubio, D.M., Berg-Weger, M., Tebb, S.S., Lee, E.S. \& Rauch, S., 2003, 'Objectifying content validity: conducting a content validity study in social work research', Social Work Research 27(2), 94-104. http://dx.doi.org/10.1093/swr/27.2.94

Talam, N.C., Gatongi, P., Rotich, J. \& Kimaiyo, S., 2008, 'Factors affecting antiretroviral drug adherence among HIV/AIDS adults patients attending HIV/AIDS clinic at Mo Teaching and Referral Hospital, Eldoret, Kenya', East African Journal of Public Health 5(2), 74-78.

Tewksbury, R., 2009, 'Qualitative versus quantitative methods: understanding why qualitative methods are superior for criminology and criminal justice', Journal of Theoretical and Philosophical Criminology 1(1), 38-58.

Trotta, M.P., Cozzi-Lepri, A., Ammassari, A., Vecchiet, J., Cassola, G., Caramello, P. et al., 2010, 'Rate of CD4+ cell count increase over periods of viral load suppression: Relationship with the number of previous virological failures', Clinical Infectious Diseases 51(4), 456-464. http://dx.doi.org/10.1086/655151

Wakibi, S.N., Ng'ang'a, Z.W. \& Mbugua, G.G., 2011, 'Factors associated with nonadherence to highly active antiretroviral therapy in Nairobi, Kenya', AIDS Research adherence to highly active antiretroviral therapy in Nairobi, Ken

Wasti, S.P., Simkhada, P., Randall, J., Freeman, J.V. \& Van Teijlingen, E., 2012, 'Factors influencing adherence to antiretroviral treatment in Nepal: A mixed-methods study' PLOS ONE 7(5), e35547. http://dx.doi.org/10.1371/journal.pone.0035547

Woods, D., Cope, F. \& Eley, B., 2008, 'The challenge of providing HIV training to health professionals', Southern African Journal of HIV Medicine 9(3), 15-17.

World Health Organization, 2006a, Progress on global access to HIV antiretroviral therapy: A report on ' 3 by 5' and beyond, WHO, Geneva, Switzerland.

World Health Organization, 2006b, From access to adherence: The challenges of antiretroviral treatment - studies from Botswana, Tanzania and Uganda, 2006, WHO, Geneva, Switzerland.

World Health Organization, 2013, Global update on HIV treatment 2013: Results, impact and opportunities, WHO, Geneva, Switzerland. 